Greta M., Tomczak-Woźniak E., Processes of monetary integration - the Greek crisis and its infuence on the European Union, „Economics and Law”, Polszakiewicz B., Boehlke J. (ed.), Vol. 13, No. 1/2014, pp. 121-134. DOI: http://dx.doi.org/10.12775/EiP.2014.010.

\author{
MarianNa GRETA* EWA TOMCZAK-WoŹNIAK ${ }^{* *}$
}

\title{
PROCESSES OF MONETARY INTEGRATION - THE GREEK CRISIS AND ITS INFLUENCE ON THE EUROPEAN UNION
}

\author{
SUMMARY
}

Meeting of the convergence criteria adopted in the Maastricht Treaty allows to ensure the stability of the zone and to increase its position in the international arena. For this to happen, achieving of the required level of convergence must be long-term and based on sound evidence. Greece when it joined the Eurozone has much abused the trust of the European Union (EU) authorities when using false data it secured its place among the other holders of the Euro currency. The intention of the paper is to present basing on the example of Greece, the importance of compliance with the convergence criteria imposed by the European Union, and its purpose is to analyze the causes of the Greek crisis and its impact on the functioning of the Eurozone and the EU.

Keywords: monetary integration, Greek crisis, Eurozone

JEL Classification: E66, E65, O52

Marianna Greta, Lodz University of Technology, Faculty of Organization and Management, Department of European Integration and International Marketing, ul. Wólczańska 215, 90-924 Lodz, phone: +48 4263555 12, e-mail: kieimm@p.lodz.pl (corresponding author).

* Ewa Tomczak-Woźniak, Lodz University of Technology, Faculty of Organization and Management, Department of European Integration and International Marketing, ul. Wólczańska 215, 90-924 Lodz, phone: +48 4263136 81, e-mail: ewa.tomczak@p.lodz.pl. 


\section{INTRODUCTION}

Since 2008, when the world experienced a great financial crisis, more and more talk is made about the problem of debt among the Euro zone countries. A particularly striking example of the problem became Greece, which in 2010 stood on the verge of bankruptcy. Despite considerable financial support from the other EU member states, the European debt crisis remains unresolved, and further countries such as Portugal, Cyprus and Spain called for assistance in handling their debt.

The problem of debt of the euro zone countries, which became the direct cause of the deepening of the global financial crisis, is an increasingly common topic of conversation among the main European Union institutions and representatives of individual Euro zone countries. The dramatic course and the depth of the recession in Greece clearly showed the weakness of institutional and managerial structures of the euro zone. Greek lesson was unusually important because from one side it showed "institutional immaturity" of euro zone, but from second side it was unpredictably effective impulse for deepening integration process. Previous assumptions, on which the whole Euro zone was based, were insufficient to protect Europe from the global recession, which is why further reforms are undertaken, in order to avoid similar situations. The intention of this paper is to present, basing on the example of Greece, the meaning of compliance with the convergence criteria imposed by the European Union (EU), and its purpose is to analyze the causes of the Greek crisis and its impact on the functioning of the Euro zone and the EU.

\section{HISTORY OF THE MONETARY UNION AS AN INTRODUCTION TO THE ISSUE}

For understanding issues of political and economical reasons of the crisis in Greece (taken into consideration in the next part of the article), authors deemed that for the beginning an attention should be gave to the brief history of the formation of the monetary union in Europe.

Roots of monetary integration should be sought in the beginnings of the integration processes in Europe. However, in the 50s the matter of the currency system integration was not the main objective of the European Economic Community (EEC), as the international system established at Bretton Woods functioned without major disruptions. Under this agreement the In- 
ternational Monetary Fund and the International Bank for Reconstruction and Development were established, and an obligation was imposed on all Member States to maintain their exchange rates within an one percent tolerance range ${ }^{1}$. Therefore, the provisions of the EEC Treaty recognized monetary affairs as belonging to the competence of the Member States.

The collapse in 1971 of the Bretton Woods system gave a strong impulse to take action in the direction of monetary integration in Europe. In 1972, on the basis of the implemented Werner Plan, the EEC countries have adopted a new currency policy, the so-called "Currency snake", stabilizing exchange rates between the countries of the Commonwealth. Also this solution was only temporary. The growing inflation, the deepening disparity in the level of economic development of separate countries, as well as increased tensions in the international monetary system contributed to the collapse of the Werner Plan. To prevent another crisis the European Monetary System (EMS) was established, under which new currency - the European Currency Unit (ECU) was created, also a new monetary mechanism and credit mechanism for the central banks of the Member States were introduced.

Since 1992 by the Treaty of Maastricht, the European Communities have been converted into the European Union. Then steps were undertaken to extend the current policy of monetary integration, resulting in the establishment of the Economic and Monetary Union. It was also decided that, starting from 1999 a monetary union will begin to operate, and the states included in the group will use a single currency - the euro. In accordance with the provisions of the Treaty, the country could replace their currency with an European currency when the country seeking to adopt it meets certain economic conditions called the convergence criteria.

Just before the official introduction of the Euro into circulation the Stability and Growth Pact was signed, aimed at ensuring budgetary discipline within the Economic and Monetary Union, and a new exchange rate mechanism - ERM II - was established. On the $1^{\text {st }}$ of January 1999 there took place a liquidation of national currencies and the introduction of the Euro. The zone was not joined by only four countries of the European Union: the United Kingdom and Denmark, which have not allowed for to the introduction of a common currency, and signed the opt-out clause, under which they can decide about their monetary future for themselves, as well as Sweden and Greece, which then did not meet the convergence criteria. It was not until three years later when Greece became a member of the Eurosystem.

\footnotetext{
${ }^{1}$ PWNBiznes.pl, Bretton Woods system, http://biznes.pwn.pl/index.php?module=haslo\& $\mathrm{id}=3880620(15.06 .2013)$.
} 


\section{THE FULFILLMENT OF THE CONVERGENCE CRITERIA BY THE GREECE AND OTHER EURO ZONE COUNTRIES}

The European Central Bank evaluates the degree of economic convergence of the candidate countries to adopt the euro as a legal tender according to a uniform pattern. For the country to introduce the Euro, it must meet the following criteria:

- maintaining of the budget deficit below 3\% of GDP,

- maintaining of the public debt below $60 \%$ of GDP,

- the level of long-term interest rate (it may be higher by max. 2\% from the average for the three Euro zone countries with the lowest inflation),

- stable prices (inflation rate can not be higher by more than $1.5 \%$ compared to the average for the three Euro zone countries with the lowest inflation),

- participation of the domestic currency in the ERM for at least two years before joining the Euro zone ${ }^{2}$.

These criteria are used to assess the future and current economic situation of the candidate countries. However, to ensure the sustainability of economic convergence, and thus the future stability of the Euro zone, the ECB uses anumber of additional indicators of a predicting character. Indeed, achieving a strong starting position, the existence of stable institutions and an appropriate policy after the adoption of the Euro is one of the indicators of the success of monetary integration ${ }^{3}$.

The accepted fiscal criteria reference values are a rigid base used to monitor the state of public finances of Member States". Table 1 shows how the budget deficit level was formed in the Member States. The year denoted by color means that the country was already a member of the Eurosystem, where a bright shade means membership of the country and meeting of the criterion, and the dark shade means a country belonging to the zone with a crossed threshold of convergence. As it can be seen, in the period to 2008 (breakthrough year due to the visibility of the crisis) the only country that at the time of adoption of the Euro did not meet the debt criterion was Greece.

${ }^{2}$ J. Galster, Z. Witkowski, K.M. Witkowska, Kompendium wiedzy o Unii Europejskiej, TNOiK, Toruń 2006, p. 15.

${ }^{3}$ European Central Bank, Convergence Report May 2012, Frankfurt 2012, p. 7.

${ }^{4}$ A. Nowak-Far, Unia Gospodarcza i Walutowa w Europie, Wydawnictwo CH Beck, Warszawa 2001, pp. 35-42. 
Moreover, the Greek budget deficit deepened from year to year, and in 2009 reached a peak of $15.6 \%$ of GDP.

Table 1. The budget deficit in the Euro zone (\% of GDP)

\begin{tabular}{|c|c|c|c|c|c|c|c|c|c|c|c|c|c|}
\hline CounTRY & 1999 & 2000 & 2001 & 2002 & 2003 & 2004 & 2005 & 2006 & 2007 & 2008 & 2009 & 2010 & 2011 \\
\hline Belgium & -0.6 & 0.0 & 0.4 & -0.1 & -0.1 & -0.1 & -2.5 & 0.4 & -0.1 & -1.0 & -5.5 & -3.8 & -3.7 \\
\hline Germany & -1.6 & 1.1 & -3.1 & -3.8 & -4.2 & -3.8 & -3.3 & -1.6 & 0.2 & -0.1 & -3.1 & -4.1 & -0.8 \\
\hline Estonia & -3.5 & -0.2 & -0.1 & 0.3 & 1.7 & 1.6 & 1.6 & 2.5 & 2.4 & -2.9 & -2.0 & 0.2 & 1.1 \\
\hline Ireland & 2.6 & 4.7 & 0.9 & -0.4 & 0.4 & 1.4 & 1.7 & 2.9 & 0.1 & -7.4 & -13.9 & -30.9 & -13.4 \\
\hline Greece & - & -3.7 & -4.5 & -4.8 & -5.6 & -7.5 & -5.2 & -5.7 & -6.5 & -9.8 & -15.6 & -10.7 & -9.4 \\
\hline Spain & -1.2 & -0.9 & -0.5 & -0.2 & -0.3 & -0.1 & 1.3 & 2.4 & 1.9 & -4.5 & -11.2 & -9.7 & -9.4 \\
\hline France & -1.8 & -1.5 & -1.5 & -3.1 & -4.1 & -3.6 & -2.9 & -3.3 & -2.7 & -3.3 & -7.5 & -7.1 & -5.2 \\
\hline Italy & -1.9 & -0.8 & -3.1 & -3.1 & -3.6 & -3.5 & -4.4 & -3.4 & -1.6 & -2.7 & -5.4 & -4.5 & -3.9 \\
\hline Cyprus & -4.3 & -2.3 & -2.2 & -4.4 & -6.6 & -4.1 & -2.4 & -1.2 & 3.5 & 0.9 & -6.1 & -5.3 & -6.3 \\
\hline Luxembourg & 3.4 & 6.0 & 6.1 & 2.1 & 0.5 & -1.1 & 0.0 & 1.4 & 3.7 & 3.2 & -0.8 & -0.8 & -0.3 \\
\hline Malta & -7.2 & -5.8 & -6.4 & -5.8 & -9.2 & -4.7 & -2.9 & -2.8 & -2.3 & -4.6 & -3.9 & -3.6 & -2.7 \\
\hline Netherlands & 0.4 & 2.0 & -0.2 & -2.1 & -3.1 & -1.7 & -0.3 & 0.5 & 0.2 & 0.5 & -5.6 & -5.1 & -4.5 \\
\hline Austria & -2.3 & -1.7 & 0.0 & -0.7 & -1.5 & -4.4 & -1.7 & -1.5 & -0.9 & -0.9 & -4.1 & -4.5 & -2.5 \\
\hline Portugal & -3.1 & -3.3 & -4.8 & -3.4 & -3.7 & -4.0 & -6.5 & -4.6 & -3.1 & -3.6 & -10.2 & -9.8 & -4.4 \\
\hline Slovenia & -3.0 & -3.7 & -4.0 & -2.4 & -2.7 & -2.3 & -1.5 & -1.4 & 0.0 & -1.9 & -6.0 & -5.7 & -6.4 \\
\hline Slovakia & -7.4 & -12.3 & -6.5 & -8.2 & -2.8 & -2.4 & -2.8 & -3.2 & -1.8 & -2.1 & -8.0 & -7.7 & -4.9 \\
\hline Finland & 1.7 & 7.0 & 5.1 & 4.2 & 2.6 & 2.5 & 2.9 & 4.2 & 5.3 & 4.4 & -2.5 & -2.5 & -0.6 \\
\hline
\end{tabular}

Source: Own elaboration based on Eurostat, www.ec.europa.eu/eurostat (15.02.2013).

Analyzing the data in table 1 it can be concluded that the global economic crisis has caused a sharp increase in the deficit of the Euro zone countries. Already in 2009, most countries have experienced a rapid growth in the budget deficit. Excessive deficit contributed to the growth of public debt and related maintenance costs.

Table 2. Public debt in the Euro zone countries (\% of GDP)

\begin{tabular}{|c|c|c|c|c|c|c|c|c|c|c|c|c|c|}
\hline CountRY & 1999 & 2000 & 2001 & 2002 & 2003 & 2004 & 2005 & 2006 & 2007 & 2008 & 2009 & 2010 & 2011 \\
\hline Belgium & 113.6 & 107.8 & 106.5 & 103.4 & 98.4 & 94.0 & 92.0 & 88.0 & 84.0 & 89.2 & 95.7 & 95.5 & 97.8 \\
\hline Germany & 61.3 & 60.2 & 59.1 & 90.7 & 64.4 & 66.2 & 68.5 & 68.0 & 65.2 & 66.8 & 74.5 & 82.5 & 80.5 \\
\hline Estonia & 6.5 & 5.1 & 4.8 & 5.7 & 5.6 & 5.0 & 4.6 & 4.4 & 3.7 & 4.5 & 7.2 & 6.7 & 6.1 \\
\hline Ireland & 47.0 & 35.1 & 35.2 & 32.0 & 30.7 & 29.5 & 27.3 & 24.6 & 25.1 & 44.5 & 64.9 & 92.2 & 106.4 \\
\hline Greece & 94.0 & 103.4 & 103.7 & 101.7 & 97.4 & 98.6 & 100.0 & 106.1 & 107.4 & 112.9 & 129.7 & 148.3 & 170.6 \\
\hline Spain & 62.4 & 59.4 & 55.6 & 52.6 & 48.8 & 46.3 & 43.2 & 39.7 & 36.3 & 40.2 & 53.9 & 61.5 & 69.3 \\
\hline France & 58.9 & 57.3 & 56.9 & 58.8 & 62.9 & 64.9 & 66.4 & 63.7 & 64.2 & 68.2 & 79.2 & 82.3 & 86.0 \\
\hline Italy & 113.0 & 108.5 & 108.2 & 105.1 & 103.9 & 103.4 & 105.7 & 106.3 & 103.3 & 106.1 & 119.4 & 119.2 & 120.7 \\
\hline
\end{tabular}




\begin{tabular}{|c|c|c|c|c|c|c|c|c|c|c|c|c|c|}
\hline CountRY & 1999 & 2000 & 2001 & 2002 & 2003 & 2004 & 2005 & 2006 & 2007 & 2008 & 2009 & 2010 & 2011 \\
\hline Cyprus & 59.3 & 59.6 & 61.2 & 65.1 & 69.7 & 70.9 & 69.4 & 64.7 & 58.8 & 48.9 & 58.5 & 61.3 & 71.1 \\
\hline Luxembourg & 6.4 & 6.2 & 6.3 & 6.3 & 6.1 & 6.3 & 6.1 & 6.7 & 6.7 & 14.4 & 15.3 & 19.2 & 18.3 \\
\hline Malta & 57.1 & 54.9 & 60.5 & 59.1 & 67.6 & 71.7 & 69.7 & 64.0 & 61.9 & 62.0 & 67.6 & 68.3 & 70.9 \\
\hline Netherlands & 61.1 & 53.8 & 50.7 & 50.5 & 52.0 & 52.4 & 51.8 & 47.4 & 45.3 & 58.5 & 60.8 & 63.1 & 65.5 \\
\hline Austria & 66.8 & 66.2 & 66.8 & 66.2 & 65.3 & 64.7 & 64.2 & 62.3 & 60.2 & 63.8 & 69.2 & 72.0 & 72.4 \\
\hline Portugal & 51.4 & 50.7 & 53.8 & 56.8 & 59.4 & 61.9 & 67.7 & 69.4 & 68.4 & 71.7 & 83.2 & 93.4 & 108.1 \\
\hline Slovenia & 24.1 & 26.3 & 26.5 & 27.8 & 27.2 & 27.3 & 26.7 & 26.4 & 23.1 & 22.0 & 35.0 & 38.6 & 46.9 \\
\hline Slovakia & 47.8 & 50.3 & 48.9 & 43.4 & 42.4 & 41.5 & 34.2 & 30.5 & 29.6 & 27.9 & 35.6 & 41.0 & 43.3 \\
\hline Finland & 45.7 & 43.8 & 42.5 & 41.5 & 44.5 & 44.4 & 41.7 & 39.6 & 35.2 & 33.9 & 43.5 & 48.6 & 49.0 \\
\hline
\end{tabular}

Source: Own elaboration based on Eurostat, www.ec.europa.eu/eurostat (15.02.2013).

According to the accepted values of the convergence criteria, public debt must not exceed $60 \%$ of GDP. Too heavily indebted countries may fall into the so-called vicious circle. Table 2 shows the size of the public debt of individual countries. Finland and Luxembourg are the only countries that throughout the whole period of belonging to the zone did not exceed the threshold enshrined in the Maastricht Treaty. And Greece, Belgium and Italy are the countries that since the launch of the Euro zone exceeded this threshold two or even three times, but in Greece's public debt grew the quickest and reached a catastrophic level of more than $170 \%$ of GDP.

A candidate country to the euro zone must also demonstrate the ability to maintain a stable price level. The ability to control inflation and the desire to systematically lower it is indicated as the most important prerequisite for sustainable economic growth and social welfare. In the Euro zone it is required not only to achieve a sustainable degree of price stability at the time of entering the zone, but also to maintain their stability in the following years.

In year 1998, namely just before the introduction of a common currency the countries with the lowest inflation rates were Germany, France and Austria. A year later, however, one of the countries that adopted the Euro - Ireland - still did not meet this criterion. Tendency to stabilize prices had a positive impact on public finances of the countries of the zone. Falling inflation has allowed for them to reduce the budget deficit during this period.

As shown in table 3, Greece throughout the majority of its period of belonging to the euro zone could not keep the prices within the accepted reference value of the inflation criterion. In 2008, there was a significant increase in inflation in all countries compared with the previous year. The biggest jump in inflation was recorded by Malta (4\%), Belgium (2.7\%) and Finland (2.3\%). 
The culmination was in year 2010, in which only five of the 16 Euro zone Member States fulfilled the criterion of price stability.

Table 3. The inflation rate in the euro zone countries (\% of GDP)

\begin{tabular}{|c|c|c|c|c|c|c|c|c|c|c|c|c|c|c|c|}
\hline CounTRY & 1998 & 1999 & 2000 & 2001 & 2002 & 2003 & 2004 & 2005 & 2006 & 2007 & 2008 & 2009 & 2010 & 2011 & 2012 \\
\hline Belgium & 0.9 & 1.1 & 2.7 & 2.4 & 1.6 & 1.5 & 1.9 & 2.5 & 2.3 & 1.8 & 4.5 & 0.0 & 2.3 & 3.4 & 2.6 \\
\hline Germany & 0.6 & 0.6 & 1.4 & 1.9 & 1.4 & 1.0 & 1.8 & 1.9 & 1.8 & 2.3 & 2.8 & 0.2 & 1.2 & 2.5 & 2.1 \\
\hline Estonia & 8.8 & 3.1 & 3.9 & 5.6 & 3.6 & 1.4 & 3.0 & 4.1 & 4.4 & 6.7 & 10.6 & 0.2 & 2.7 & 5.1 & 4.2 \\
\hline Ireland & 2.1 & 2.5 & 5.3 & 4.0 & 4.7 & 4.0 & 2.3 & 2.2 & 2.7 & 2.9 & 3.1 & -1.7 & -1.6 & 1.2 & 1.9 \\
\hline Greece & 4.5 & 2.1 & 2.9 & 3.7 & 3.9 & 3.4 & 3.0 & 3.5 & 3.3 & 3.0 & 4.2 & 1.3 & 4.7 & 3.1 & 1.0 \\
\hline Spain & 1.8 & 2.2 & 3.5 & 2.8 & 3.6 & 3.1 & 3.1 & 3.4 & 3.6 & 2.8 & 4.1 & -0.2 & 2.0 & 3.1 & 2.4 \\
\hline France & 0.7 & 0.6 & 1.8 & 1.8 & 1.9 & 2.2 & 2.3 & 1.9 & 1.9 & 1.6 & 3.2 & 0.1 & 1.7 & 2.3 & 2.2 \\
\hline Italy & 2.0 & 1.7 & 2.6 & 2.3 & 2.6 & 2.8 & 2.3 & 2.2 & 2.2 & 2.0 & 3.5 & 0.8 & 1.6 & 2.9 & 3.3 \\
\hline Cyprus & 2.3 & 1.1 & 4.9 & 2.0 & 2.8 & 4.0 & 1.9 & 2.0 & 2.2 & 2.2 & 4.4 & 0.2 & 2.6 & 3.5 & 3.1 \\
\hline Luxembourg & 1.0 & 1.0 & 3.8 & 2.4 & 2.1 & 2.5 & 3.2 & 3.8 & 3.0 & 2.7 & 4.1 & 0.0 & 2.8 & 3.7 & 2.9 \\
\hline Malta & 3.7 & 2.3 & 3.0 & 2.5 & 2.6 & 1.9 & 2.7 & 2.5 & 2.6 & 0.7 & 4.7 & 1.8 & 2.0 & 2.5 & 3.2 \\
\hline Netherlands & 1.8 & 2.0 & 2.3 & 5.1 & 3.9 & 2.2 & 1.4 & 1.5 & 1.7 & 1.6 & 2.2 & 1.0 & 0.9 & 2.5 & 2.8 \\
\hline Austria & 0.8 & 0.5 & 2.0 & 2.3 & 1.7 & 1.3 & 2.0 & 2.1 & 1.7 & 2.2 & 3.2 & 0.4 & 1.7 & 3.6 & 2.6 \\
\hline Portugal & 2.2 & 2.2 & 2.8 & 4.4 & 3.7 & 3.3 & 2.5 & 2.1 & 3.0 & 2.4 & 2.7 & -0.9 & 1.4 & 3.6 & 2.8 \\
\hline Slovenia & 7.9 & 6.1 & 8.9 & 8.6 & 7.5 & 5.7 & 3.7 & 2.5 & 2.5 & 3.8 & 5.5 & 0.9 & 2.1 & 2.1 & 2.8 \\
\hline Slovakia & 6.7 & 10.4 & 12.2 & 7.2 & 3.5 & 8.4 & 7.5 & 2.8 & 4.3 & 1.9 & 3.9 & 0.9 & 0.7 & 4.1 & 3.7 \\
\hline Finland & 1.3 & 1.3 & 2.9 & 2.7 & 2.0 & 1.3 & 0.1 & 0.8 & 1.3 & 1.6 & 3.9 & 1.6 & 1.7 & 3.3 & 3.2 \\
\hline Reference & 2.2 & 2.1 & 3.2 & 3.5 & 3.1 & 2.7 & 2.6 & 2.9 & 3.1 & 3.1 & 4.1 & 0.7 & 1.5 & 3.4 & 3.2 \\
\hline value & & & & & & & & & & & & & & \\
\hline
\end{tabular}

Source: Own elaboration based on Eurostat, www.ec.europa.eu/eurostat (15.02.2013).

Adoption of the level of long term interest rates as an indicator of degree of convergence of candidate countries in the Euro zone was due to the fact that these rates are a kind of reflection of the economic situation of these countries, in particular they provide a picture of the sustainability of economic results achieved by them in terms of price stability and public finances. Interest rates are be measured on the basis of long-term government bonds or comparable governmental securities, taking into account differences in national definitions ${ }^{5}$.

${ }^{5} \mathrm{~J}$. Borowiec, Unia ekonomiczna i monetarna. Historia, podstawy teoretyczne, polityka, Wydawnictwo Akademii Ekonomicznej im. O. Langego, Wrocław 2001, pp. 12 and further. 
Table 4. Interest rates in the Euro zone countries (\% of GDP)

\begin{tabular}{|c|c|c|c|c|c|c|c|c|c|c|c|c|c|c|c|}
\hline CountRY & 1998 & 1999 & 2000 & 2001 & 2002 & 2003 & 2004 & 2005 & 2006 & 2007 & 2008 & 2009 & 2010 & 2011 & 2012 \\
\hline Belgium & 4.8 & 4.8 & 5.6 & 5.1 & 5.0 & 4.2 & 4.2 & 3.4 & 3.8 & 4.3 & 4.4 & 3.9 & 3.5 & 4.2 & 3.0 \\
\hline Germany & 4.6 & 4.5 & 5.3 & 4.8 & 4.8 & 4.1 & 4.0 & 3.4 & 3.8 & 4.2 & 4.0 & 3.2 & 2.7 & 2.6 & 1.5 \\
\hline Estonia & - & - & - & - & - & - & - & - & - & - & - & - & - & - & - \\
\hline Ireland & 4.8 & 4.7 & 5.5 & 5.0 & 5.0 & 4.1 & 4.1 & 3.3 & 3.8 & 4.3 & 4.5 & 5.2 & 5.7 & 9.6 & 6.2 \\
\hline Greece & 8.5 & 6.3 & 6.1 & 5.3 & 5.1 & 4.3 & 4.3 & 3.6 & 4.1 & 4.5 & 4.8 & 5.2 & 9.1 & 15.8 & 22.5 \\
\hline Spain & 4.8 & 4.7 & 5.5 & 5.1 & 5.0 & 4.1 & 4.1 & 3.4 & 3.8 & 4.3 & 4.4 & 4.0 & 4.3 & 5.4 & 5.9 \\
\hline France & 4.6 & 4.6 & 5.4 & 4.9 & 4.9 & 4.1 & 4.1 & 3.4 & 3.8 & 4.3 & 4.2 & 3.7 & 3.1 & 3.3 & 2.5 \\
\hline Italy & 4.9 & 4.7 & 5.6 & 5.2 & 5.0 & 4.3 & 4.3 & 3.6 & 4.1 & 4.5 & 4.7 & 4.3 & 4.0 & 5.4 & 5.5 \\
\hline Cyprus & - & - & - & 7.6 & 5.7 & 4.7 & 5.8 & 5.2 & 4.1 & 4.5 & 4.6 & 4.6 & 4.6 & 5.8 & 7.0 \\
\hline $\begin{array}{c}\text { Luxembo- } \\
\text { urg }\end{array}$ & 4.7 & 4.7 & 5.5 & 4.9 & 4.7 & 3.3 & 2.8 & 2.4 & 3.3 & 4.5 & 4.6 & 4.2 & 3.2 & 2.9 & 1.8 \\
\hline Malta & - & - & - & 6.2 & 5.8 & 5.0 & 4.7 & 4.6 & 4.3 & 4.7 & 4.8 & 4.5 & 4.2 & 4.5 & 4.1 \\
\hline $\begin{array}{c}\text { Nether- } \\
\text { lands }\end{array}$ & 4.6 & 4.6 & 5.4 & 5.0 & 4.9 & 4.1 & 4.1 & 3.4 & 3.8 & 4.3 & 4.2 & 3.7 & 3.0 & 3.0 & 1.9 \\
\hline Austria & 4.7 & 4.7 & 5.6 & 5.1 & 5.0 & 4.1 & 4.1 & 3.4 & 3.8 & 4.3 & 4.4 & 3.9 & 3.2 & 3.3 & 2.4 \\
\hline Portugal & 4.9 & 4.8 & 5.6 & 5.2 & 5.0 & 4.2 & 4.1 & 3.4 & 3.9 & 4.4 & 4.5 & 4.2 & 5.4 & 10.2 & 10.6 \\
\hline Slovenia & - & - & - & - & 8.7 & 6.4 & 4.7 & 3.8 & 3.9 & 4.5 & 4.6 & 4.4 & 3.8 & 5.0 & 5.8 \\
\hline Slovakia & - & - & - & 8.0 & 6.9 & 5.0 & 5.0 & 3.5 & 4.4 & 4.5 & 4.7 & 4.7 & 3.9 & 4.5 & 4.6 \\
\hline \begin{tabular}{c} 
Finland \\
\hline Reference \\
value
\end{tabular} & 4.8 & 4.7 & 5.6 & 5.0 & 5.0 & 4.1 & 4.1 & 3.4 & 3.8 & 4.3 & 4.3 & 3.7 & 3.0 & 3.0 & 1.9 \\
\hline Soure: Ow & 6.6 & 7.4 & 6.9 & 6.9 & 6.1 & 6.1 & 5.4 & 5.8 & 6.3 & 6.2 & 6.5 & 6.2 & 8.0 & 12.1 \\
\hline
\end{tabular}

Source: Own elaboration based on Eurostat, www.ec.europa.eu/eurostat (15.02.2013).

The reference group for this criterion is the same as in case of the criterion for stability of prices. At the time of the creation of Euroland, this criterion was fulfilled by all of the EU countries, although some of them fell under the limit value. As late as in 2010, the reference value was exceeded by Greece (3\%) and the following year it was joined by Ireland and Portugal.

\section{THE GREEK CRISIS AND ITS IMPACT ON THE EURO ZONE}

The causes of the Greek crisis are largely due to insufficient preparation of this country for integration with the euro zone. During the 15 years of participation of Greece in the EU it was losing its distance to the rest of the countries of united Europe, both in the real and nominal area. After another five years, the country was incorporated into the Euroland, having passed a short, turbulent and dynamic period of growth of individual fiscal consolidation and disinflation process, which are the factors necessary for 
the fulfillment of the convergence criteria. However, the strategy of economic adjustment to the desired by the EU level of stability was based only on short-term measures, and the lack of reforms with medium and long term results meant, that Greece joined the eurozone as a country with a worst level of convergence ${ }^{6}$.

Joining of Greece to the euro zone caused a decrease in the cost of capital and credit growth, which negatively affected the level of inflation in the country. The increased inflationary pressure was reflected in further real appreciation deepening the exchange rate overvaluation. This situation caused a deterioration of the already poor competitiveness of the sector of goods directly related to international trade. The trend of decreasing share of the sector of these goods in GDP growth is a serious threat to the country's development, as it is these goods that are usually the engine of technological progress in the economy ${ }^{7}$. In addition, many economists assume that the decrease in cost of capital due to the accession to the euro zone should have a positive impact on both investment growth and the decline in the level of domestic savings. In Greece, however, only the second relationship was noted. The capital borrowed on international markets should eventually lead to an increase of the attractiveness of exports, which would create opportunities for the repayment of the debt in the future. In case of Greece, however, it was used inefficiently, and the obtained resources were mainly allocated to financing of consumption in the private and public sectors ${ }^{8}$.

After joining the euro zone, the central bank of the new member delegates most of the rights to the formation of monetary policy to the Council of the European Central Bank (ECB) Governors. ECB cooperates closely with the central banks of countries that adopt the euro, but it has a decisive vote in matters of the single monetary policy in each Euroland country. In this situation Greece has not been able to influence the level of competitiveness of their domestic products by modeling the nominal exchange rate. The Greek government should then focus on lowering of inflation in other countries, especially those that are the major trading partners of Greece.

The structure of spendings of the Greek government sector, which is still dominated by spending on social transfers and public sector wages, has a neg-

${ }^{6}$ A. Vamvakidis, The convergence of the Greek economy in the EU: lessons for accession countries, NBP, Warsaw 2003, pp. 7-15.

${ }^{7}$ M. Rozkurut, R. Woreta, Sukcesy i porażki Grecji na drodze do strefy euro. Wnioski dla nowych krajów UE, NBP, Warsaw 2005, p 34.

${ }^{8}$ F. Jaumotte, P. Sodsriwiboon, Current Account Imbalances in the Southern Euro Area, IMF Working Paper, No. 10/139/2010, p 4. 
ative impact on economic growth. Increased spendings in these areas stimulate private sector consumption, which in turn leads to an increase in the consumer goods price inflation indicator ${ }^{9}$. Furthermore, in Greece since October 2000 the level of inflation exceeded the permitted level (table 3.).

The Greek government after joining the euro zone also did not follow the other convergence objectives, set by the Maastricht Treaty, as evidenced by the fact that the budget deficit after 2001 never fell below the reference level of $3 \%$ of GDP (table 1.). Lower interest rates on bonds meant that the cost of deficit maintenance was declining. Before the outbreak of the global financial crisis, the cost was characterized by a low sensitivity to changing fiscal situation of the issuer of the bonds. However, Greece over-used that relationship as evidenced by the structural nature of the Greek budget deficit ${ }^{10}$. Expenditures in subsequent years systematically increased and exceeded the expected levels, and the overly optimistic assumptions about tax revenues and their low chargeability imbued the growing indebtedness of the country.

Manipulations came to light in the following years. Already in 2004, the Greece's budget deficit reached 7.5\% of GDP. Even in 2005, it was slightly lowered, but the subsequent years showed the weakness of the Greek economy and the Greek government's incompetence in matters of stabilization of national finances. It turned out that in spite of warnings after the revision made in 2004, the Greek authorities continued to send in erroneous statistical data to Eurostat. Re-revision was performed in 2009, when the budget deficit level reached $15.6 \%$ of GDP. The growing budget deficit inevitably led to the increase of the public debt. Since the accession of Greece to the euro zone the public debt levels in each subsequent year continued to stay above the level of 100\% of GDP (with the exception of the years 2003 and 2004). Low costs of debt maintenance meant that before the outbreak of the global financial crisis (2008), even such high levels of debt could be maintained. This situation changed drastically after 2008. The increase in yields on bonds issued to maintain the debt caused a drastic deterioration in the public finances of Greece. The debt has grown at an alarming rate (table 2.).

Information about the revision of Greek data resulted in lower credit ratings of the country, which resulted in an immediate drop in prices of Greek assets in the financial markets. At the end of 2009 the process of lowering ratings for Greece by all rating agencies began. Further rating downgrades of Greece meant that its fiscal securities gained the status of "junk bonds". Such

${ }_{9}$ Ministry of Finance of the Republic of Poland, Greek crisis - genesis and consequences, Warsaw 2010, p. 12-13.

${ }^{10}$ European Commission, The Economic Adjustment Programme for Greece, Brussels 2010, p. 4. 
a rapid decline in prices of Greek bonds is a response to a significant increase in the risk of bankruptcy of this country.

The above results in that only through creative accounting of the Greek government the country has been accepted to the members of the euro zone, when in fact it did not meet the requirements of the Maastricht Treaty. For this reason, other eurozone countries and the EU institutions fully accepted that they bear partial blame for the situation. No relevant departments worked which continuously control the situations in the Member States, and the created instruments (Stability and Growth Pact) have failed. In May 2010, the European Union and the International Monetary Fund announced that they will accept part of the burden of the mistakes of the past, giving Greece the first tranche of aid of $€ 110$ billion. But soon it became clear that Greece's economic problems are not the only example, and the "disease" of economies will spread to other economically weaker member states. EU finance heads decided then to set up a Stabilizing Mechanism with an initial capital of 500 billion euros, which was an extension of the rescue package for countries with and also showing the evidence of existence of problems with repayment of their debts in the future.

The outbreak of the global financial crisis has forced major EU institutions to take appropriate measures to reform the existing arrangements for financial stability. In the case of increase of severity of the problem of overindebtedness in the euro zone and the existence of threat of bankruptcy of one of its members, the EU has not been able to take immediate action to prevent this situation due to the lack of appropriate procedures. It was not until the crisis of Greek public finances when the institutional weaknesses of the euro zone was discovered and at the same time became the starting point for discussions about the reforms. Thanks to it appropriate changes were made to improve the process of eradication of possible financial crises in the future.

\section{CONCLUSIONS}

Meeting of the convergence criteria adopted in the Maastricht Treaty ensures the stability of the whole zone and improves its position in the international arena. For this to happen, achieving of the required degree of convergence must be long-term and based on reliable data.

Greece, when joining the euro zone greatly abused the trust of EU bodies, when using false data it secured its place among the other holders of the euro. Although most of the irregularities came to light a few years later, 
Greece still remained in the Eurosystem. Unfortunately, this has led to further problems and the economic slowdown in the euro zone.

The economic crisis of Greece was a very important lesson for the EU. It gave birth to changes in the laws on action in case of a global economic slowdown. A number of changes to ensure greater stability zone were made. Steps were taken to better control the zone candidate countries and its members. Also an appropriate mechanism to protect the euro zone members facing similar crises was established. Moreover the Greek lesson is entailing the following conclusions ${ }^{11}$ :

Filling up of the convergence criteria must have permanent character, and major reforms should be conducted (anyway begun) still before entering currency into the ERM mechanism II.

For the filling of formal conditions of revoking the derogation the efforts should be accompanied by actions increasing the effectiveness of alternative mechanism of the absorption of shocks, so as the channel of the competitiveness and the fiscal channel. The reaction rate of the economy to asymmetrical shocks will depend on the elasticity of the product market and of the labour market, on the low structural deficit level, as well as on the rational fiscal policy and the effectiveness of the financial control.

Greek experience showed that Greece in the moment of the accession was not prepared for the adoption of the euro. It should be expected that in case of next evaluations in Reports on the convergence the European Commission and the European Central Bank will put much greater weight to the permanence of filling criteria up.

The crisis of the Greek public finance brought to the situation, in which the more and more large number of decisions is being taken on the forum of countries of the euro zone, rather than of all countries of the European Union

\section{BIBLIOGRAPHY}

Borowiec J., Unia ekonomiczna i monetarna. Historia, podstawy teoretyczne, polityka, Wydawnictwo Akademii Ekonomicznej im. O. Langego, Wrocław, 2001.

European Central Bank, Convergence Report May 2012, Frankfurt 2012.

European Commission, The Economic Adjustment Programme for Greece, Brussels 2010, p. 4.

Eurostat, www.ec.europa.eu/eurostat (15.02.2013).

${ }^{11}$ Ministry of Finance of the Republic of Poland, Greek crisis - genesis and consequences, Warsaw 2010, p. 37-39. 
Galster J., Witkowski Z., Witkowska K.M., Kompendium wiedzy o Unii Europejskiej, TNOiK, Torun 2006.

Jaumotte F., Sodsriwiboon P., Current Account Imbalances in the Southern Euro Area, IMF Working Paper, No 10/139/2010, http://dx.doi.org/10.5089/9781455201228.001.

Ministry of Finance of the Republic of Poland, Greek crisis- genesis and consequences, Warsaw 2010.

Nowak-Far A., Unia Gospodarcza i Walutowa w Europie, Wydawnictwo CH Beck, Warszawa 2001.

PWNBiznes.pl, Bretton Woods system, http://biznes.pwn.pl/index. php? module=haslo\&id=3880620 (15.06.2013).

Rozkurut M., Woreta R., Sukcesy i porażki Grecji na drodze do strefy euro. Wnioski dla nowych krajów UE, NBP, Warsaw 2005.

Vamvakidis A., The convergence of the Greek economy in the EU: lessons for accession countries, NBP, Warsaw 2003. 
